\title{
Yapay Zekâ Temalı Sosyobilimsel Konu Öğretiminin ilkokul Öğrencilerinin Problem Çözme ve Yaratıcı Yazma Becerilerine Etkisi
}

\author{
The Effect of Socioscientific Issues Teaching on Primary School Students on \\ Problem Solving and Creative Writing Skills in the Theme of Artificial \\ Intelligence
}

\begin{abstract}
Sümeyye SOYDEMIR BOR ${ }^{\text {ID }}$, Yüksek Lisans Öğrencisi, Necmettin Erbakan Üniversitesi, Eğitim Bilimleri Enstitüsü, sumeyyesoydemirbor@gmail.com
\end{abstract}

\author{
Menşure ALKIŞ KÜÇÜKAYDIN ～Doçent, Necmettin Erbakan Üniversitesi Ereğli, Eğitim Fakültesi, \\ mesurealkis@hotmail.com
}

\begin{abstract}
Soydemir Bor, S. ve Alkış Küçükaydın, M. (2021). Yapay zekâ temalı sosyobilimsel konu öğretiminin ilkokul öğrencilerinin problem çözme ve yaratıcı yazma becerilerine etkisi. Batı Anadolu Eğitim Bilimleri Dergisi, 12(2), 432-446.
\end{abstract}

Geliş tarihi:28.03. 2021

Kabul tarihi:26.08. 2021

Yayımlanma tarihi:28.12. 2021

\begin{abstract}
Öz. Bu çalışmada ilkokul 4.sınıf öğrencilerine yapay zekâ konusunda sunulan sosyobilimsel konu (SBK) öğretiminin, öğrencilerin problem çözme ve yaratıcı düşünme becerilerine olan etkisi incelenmiştir. 2020-2021 eğitim öğretim yılında Konya ilinde yer alan bir ilkokulda yapılan bu çalışma, nicel ve nitel araştırmaların kombinasyonunu içeren karma yöntem araştırmalarından yakınsayan paralel desen üzerine yapılandırılmışır. Çalışmanın nicel kısmında veri toplama aracı olarak "Çocuklar için Problem Çözme Envanteri" ile "Yaratıcı Yazma Ürünlerini Değerlendirme Ölçeği" kullanılmışır. Çalışmanın nitel kısmında ise yarı yapılandırılmış gözlem formu ile görüşme formu kullanıımıştı. Çalışmadan elde edilen sonuçlar yapay zekâ konusunda hazırlanan SBK öğretiminin öğrencilerin yaratııı yazma ve problem çözme becerilerine katkı sağladığını göstermiştir. Ayrıca sınıf içi gözlemler ile görüşmeden elde edilen bulgular, öğrencilerin yapay zekâ konusunda yürütülen SBK içerikli derslerden hoşlandıklarını ve ders içeriklerine daha rahat ulaştıklarını işaret etmiştir. Elde edilen sonuçlar ilgili literatür doğrultusunda tartışılmış ve önerilerde bulunulmuştur. Buna göre ilkokul düzeyinde farklı SBK bağlamları ele alınarak öğrencilerin farklı düzeylerdeki bilişsel gelişimlerinin araştııılması mümkündür.
\end{abstract}

Anahtar Kelimeler: Problem çözme, Sosyobilimsel konular, Yapay zekâ, Yaratıcı yazma.

\begin{abstract}
In this study, the effect of socioscientific issues (SSI) instruction, which was presented to primary school 4th-grade students in the theme of artificial intelligence, on students' problem solving and creative thinking skills was examined. This study, conducted in a primary school in Konya in the 2020-2021 academic year, was structured on the convergent mixed-method design, which includes a combination of quantitative and qualitative researches. In the quantitative part of the study, "Problem Solving Inventory for Children at the Level of Primary Education" and "Scale of Evaluating Creative Writing Products" were used as data collection tools. In the qualitative part of the study, semi-structured observation form and interview form were used. The results obtained from the study showed that SSI instruction, prepared in the theme of artificial intelligence contributed to the creative writing and problem-solving skills of the students. In addition, the results obtained from the interviews and class observations indicated that the students liked the SBK-based lessons conducted in the context of artificial intelligence and they reached the course contents more easily. The results obtained were discussed with the relevant literature and suggestions were made in this direction. Accordingly, it is
\end{abstract}


possible to investigate the cognitive development of students at different levels by considering different SSI contexts at primary school level.

Keywords: Problem solving, Socioscientific issues, Artificial intelligence, Creative writing

\section{Extended Abstract}

Introduction. Artificial intelligence, which we encounter in many different fields every day, is a concept that includes scientific and social dimensions and comes to the agenda with discussions. Considering these aspects, it is seen that artificial intelligence is a socioscientific issue (SSI). Considering the news and cartoons that are frequently used in communication media such as television and radio, it is seen that artificial intelligence concerns children as much as adults. When the literature is examined, it has been seen that the benefits of SBK-based teaching have not yet been revealed to problem-solving and creative writing skills to be carried out in this context. In this study, the effect of SBK instruction, which is presented to primary school 4th grade students in the context of artificial intelligence, on students' problem solving and creative thinking skills was examined. In this study, conducted in a primary school in Konya in the 2020-2021 academic year, the primary school 4th-grade social studies course was addressed in the context of artificial intelligence and the effect of SBK-based teaching on students' problem solving and creative writing skills. For this purpose, the sub-problems created in the study are as follows:

1. What is the effect of social studies course with SBK content offered to primary school 4thgrade students in the context of artificial intelligence on students' problem solving and creative writing skills?

2. What are the changes in students' problem solving and creative writing skills?

Method. This study was carried out with 4th grade students in a primary school in Konya in the 20202021 academic year. The study is structured on the convergent mixed-method design that includes a combination of quantitative and qualitative research methods. In the quantitative part of the study, a single group pretest-posttest experimental design was used. In the quantitative part of the study, "Problem Solving Inventory for Children at the Level of Primary Education" and "Scale of Evaluating Creative Writing Products" were used as data collection tools. In the second stage of the research, the case study, which is one of the qualitative research designs, was used. Primary school 4th grade students were considered as a single case and in this context; semi-structured interview and observation forms were used as data collection tools.

Results. Related data analysis showed that there was a significant difference between the problem solving skills and creative writing skills of the students before and after the implementation. This situation shows that the implementation contributes to students' problem-solving skills and creative writing skills. In the qualitative part of the study, the students stated that they liked the implementations carried out in the courses with SBK content conducted in the context of artificial intelligence. All of the students expressed that the topic of artificial intelligence was interesting. In addition, the students said that they wanted to learn more about coding for artificial intelligence and advanced technology applications, future professions, different computer technologies and robots. It was observed that the data obtained from the observation form confirmed the data obtained from the interview form.

Discussion and Conclusion. When the relevant literature was examined, it was seen that the benefits of SBK-based teaching to problem-solving and creative writing skills to be carried out in this context were not addressed. With this study, it was determined that SBK teaching, which was presented to students based on a current topic, was effective on both problem solving and creative thinking skills. The results obtained in this study have shown that SSI teaching is effective if a current topic is chosen according to the level of the student. Based on this situation, it is suggested to reveal different cognitive thinking structures by considering different SSI contexts. 


\section{Giriş}

Toplum içinde var olan insan değişime ve gelişime açık bir canlıdır. Bu değişim ve gelişim intiyacı insanları zaman içinde bilim ile buluşturmuştur. Bilim toplumun ihtiyaçları doğrultusunda ortaya çıkmış, toplumlar da bilimin getirdiklerinden etkilenerek yaşamını devam ettirmiştir. Ancak bilimin getirdiği yenilikler her zaman olumlu karşılanmamış kimi konuların kabulünde zorluklarla karşılaşılmıştır (Çelik, 1998). Ne var ki bilimsel gelişmelerin toplum tarafından kabul görüp görmemesi aslında bilimin tartışmaya açık bir tarafı olduğunu da işaret etmektedir (Sadler, 2004). Bilimin bu tartışmalı tarafı sosyobilimsel konu olarak ele alınıp değerlendirilmiştir (Ritchie, Tomas ve Tones, 2011). Sosyobilimsel konular (SBK), hem bilimsel hem de sosyal konuları aynı anda kapsayan ayrıca bilimi temele alan tartışmalı konular olarak tanımlanmaktadır (Yacoubian ve Khishfe, 2018). Bu konular; bilimsel temellere dayanan, toplum tarafından önem arz eden, farklı bakış açıları ile değerlendirilebilen, bilimsel içeriğe sahip, sosyal açıdan önem arz eden içeriklerdir (Atabey, Topçu ve Çiftçi, 2018). Dolayısıyla SBK; rakip görüşlerin desteklendiği, birden fazla alanda uygulamaları olan, bilimsel bir tabana sahip, çekişmeli, açık uçlu ve tam yapılandırılmamış konular olarak da ifade edilmektedir (Özcan ve Kaptan, 2020). SBK'ların sahip olduğu bu yapı, bilimsel ve sosyal içeriklerin farklı bakış açıları ile ele alınabilmesine, fayda ve zarar analizlerinin yapılmasına böylece toplumu yakından ilgilendiren ahlaki, etik, bilimsel ve siyasi boyutların tartışılmasına imkân tanımaktadır (Topçu ve Atabey, 2017).

Ulusal ve evrensel konularla ilgilenen SBK'ların öğretimi ile bireylerde eleştirel düşünme başta olmak üzere pek çok bilişsel becerinin gelişiminin desteklendiği kabul edilmektedir (Lee, Chang, Choi, Kim ve Zeidler, 2012). Bu nedenle pek çok ülkede SBK'ların öğretim programında yer almasına karar verilmiş (Özsoy ve Kılınç, 2017) böylece öğrencilerin birçok farklı alanda gelişimine katkı sağlayacağı düşünülmüştür. Bu alanlar içerisinde bilimsel okuryazarlık, etik ve ahlaki muhakeme gelişimi, informal muhakeme gelişimi, sosyobilimsel muhakeme gelişimi ile argümantasyon becerilerinin gelişimi (Öztürk ve Irmak, 2020) gibi hususlar ele alınmıştır. Ayrıca SBK'ların öğretimi yoluyla öğrencilerin diyalog kurma, kendi fikirlerini savunma, başkalarının fikirlerine karşı hoşgörü ile yaklaşma davranışları kazandırılmakta, öğrencilerin öğrenmeye karşı motive olmaları desteklenmekte, derse yönelik ilginin artması sağlanmakta ve anlamlı öğrenmeler desteklenmektedir (Atabey vd., 2018). Ancak SBK'larla ilgili bahsedilen bu faydaların elde edilmesi için sadece program değişiklikleri yeterli görülmemekte (Arslan ve Çiğdemoğlu, 2020) SBK öğretiminin, öğretmenlerin ve öğrencilerin fikirlerini rahatça savunabilecekleri bir ortamda gerçekleştirilmesi gerektiği önerilmektedir (Topçu, 2019). Bunun için öğretmen, otoritesini öğrencileri ile paylaşabilmeli, öğrenciler süreç boyunca düşüncelerini rahatça ifade edebilmeli, öğrencilerin kendisi ile aynı görüşte olan arkadaşlarını desteklemesine ve karşı görüşleri çürütmeye çalışmasına fırsat verilmeli, açık uçlu sorular ile öğrencilerin fikirlerini geliştirmelerine olanak sağlanmalıdır (Özsoy ve Kılınç, 2017). Böyle bir öğrenme ortamı oluşabilmesi için geleneksel olarak öğretmenin otorite olduğu sınıf ortamından farklı bir yapı oluşturulmalıdır. Bu yapının oluşması öğretmenin becerisine ayrıca sınıf düzeyine uygun olarak seçtiği konuyla ilişkili olabilmektedir.

SBK'larla ilgili olarak ülkemizde yürütülen çalışmalarda genellikle genetiği değiştirilmiş besinler (Baltacı, 2013; Demir ve Düzleyen, 2012; Gürbüzoğlu Yalmancı ve Gözüm, 2016; Soysal, 2012) ile nükleer enerji (Ateş ve Saraçoğlu, 2013; Demircioğlu ve Uçar, 2014; Eş, Işık Mercan ve Ayas, 2016; İşeri, 2012; Kılınç, Boyes ve Stanisstreet, 2013; Özdemir, 2014; Özdemir ve Çobanoğlu, 2008; Öztürk, 2011; Öztürk ve Türköz, 2019; Tekbıyık, 2015; Zengin, Keçeci ve Kırılmazkaya, 2012) konularına odaklanıldığı görülmektedir. Bu konulardan farklı olarak organ bağışı (Harman ve Çökelez, 2017; Tetik ve Cebesoy, 2018; Yavuz Topaloğlu ve Balkan Kıyıcı, 2018), hidroelektrik santralleri (Öztürk ve Leblebicioğlu, 2014), klonlama (Kutluca, 2012) ve kök hücre (Ural Keleş, 2018) konularındaki çalışmalarla da karşılaşılmıştır. Yurt dışında yürütülen güncel çalışmalarda ise obezite (Leung ve Cheng, 2020), bilimin alt kültürlere aktarımı (Lee, Lee ve Zeidler, 2020), bilimin doğasının 
öğretimi (Leung, 2020), antibiyotik direnci (Peel, Zangori, Friedrichsen, Hayes ve Sadler, 2019), vatandaşlık karakterleri (Kim, Ko ve Lee, 2020) ile iklim değişikliği (Peel, Sadler, Kinslow, Zangori ve Friedrichsen, 2017) gibi farklı bağlamlardan başlıkların ele alınarak incelendiği görülmektedir. Tüm bu konular önemli ve güncel olmakla birlikte ekonomiden sağlığa, eğitimden askeri boyuta tüm sahalarda farklı iş ve işleyişleri bulunan yapay zekânın SBK bağlamında ele alınmaması literatürde bir eksiklik olarak görülmektedir. Oysaki yapay zekâ, cep telefonu kullanımından hava trafik kontrol sistemlerine kadar hayatımızın her alanında yer alan ve giderek yaşantımızın daha da geniş kısımlarına müdahale ederek sürekli genişleyen bir çember hâlini almaktadır. Her gün internet, sosyal medya, televizyon gibi iletişim araçlarında yapay zekânın sunduğu yeniliklerden bahsedilmekte Elon Musk, Stephen Hawking gibi dünyaca tanınmış isimler yapay zekânın kullanımı konusunda yaptıkları uyarılarla gündeme gelmektedirler (NTV, 2020). Dini ve siyasi liderlerin yapay zekâ konusundaki düşünceleri basında yer almakta (BBC News, 2018) üstelik bu durum çizgi filmlere konu olmaktadır (I am mother, dijital tayfa, I robot, A.I.). Dolayısıyla yapay zekâ artık sadece yetişkinleri değil çocukları da ilgilendiren bir meseledir.

Yapay zekâ başlangıçta akıllı makinalar üretme mühendisliği olarak tanımlanırken zamanla öğrenme ve problem çözme gibi insanların bilişsel işlevlerini taklit eden bir bilgisayar olarak adlandırılmıştır (Taş̧̧ı ve Çelebi, 2020). Genel anlamda yapay zekâdan kastedilen; insan zekâsının sinir sistemi, gen yapısı gibi fizyolojik ve nörolojik yapısının ve doğal olayların modellenerek makinelere (bilgisayar ve yazılımlara) aktarılmasıdır (Atalay ve Çelik, 2017). Yapay zekâ multidisipliner bir kavram olup bilgisayar mühendisliği, elektronik, eğitim, kontrol, mekatronik, programlama ve felsefe gibi farklı bilim dallarının çalışma alanına girmektedir (Öztürk ve Şahin, 2018). Dolayısıyla yapay zekâ günümüzde birçok alanda karşımıza çıkan ve çağımıza damgasını vurmaya başlamış bir kavram olarak kabul edilebilir. İlkokul program kazanımları da bu kavramın ortaya çıkardığı yenilikleri işaret etmiştir. İlkokul sosyal bilgiler dersi öğretim programı incelendiğinde özel amaçlar kısmında; öğrencilerin bilim ve teknolojinin gelişim sürecini ve toplumsal yaşam üzerindeki etkilerini kavrayarak bilgi ve iletişim teknolojilerini bilinçli kullanmaları, bilimsel düşünmeyi temel alarak bilgiye ulaşma, bilgiyi kullanma ve üretmede bilimsel ahlakı gözetmeleri konusunda eğitilmelerinin söz konusu olduğundan bahsedilmektedir. Yine sosyal bilgiler dersi öğretim programının temel beceriler kısmında; öğrencilerden değişim ve sürekliliği algılama, dijital okuryazarlık, yenilikçi düşünme becerilerini kazanmaları beklenmektedir ifadelerine yer verildiği görülmektedir. Programın uygulanması konusunda dikkat edilmesi gereken hususlar kısmında ise kazanımlarla ilgili güncel ve tartışmalı konular farklı tartışma teknikleri kullanılarak problem çözme, eleştirel düşünme, kanıt kullanma, karar verme ve araştırma becerileriyle ilişkilendirilerek sınıfa taşınabilir ifadelerinin olduğu görülmektedir (Milli Eğitim Bakanlığı [MEB], 2018). Bu noktadan hareketle yapay zekâ konusu SBK bağlamında ele alınarak sosyal bilgiler dersi kazanımlarıyla ilişkilendirilebilir. Ancak bu ilişkilendirmenin SBK'dan elde edilecek faydalar açısından incelenmesi gereklidir. İlgili literatür, SBK'ya dayalı öğretimlerin bilişsel becerilerin kazandırılması noktasında sağladığı yararlardan bahsetmektedir (Alkış Küçükaydın, 2019, 2020; Yacoubian ve Khishfe, 2018). Özellikle kritik düşünme becerisine sağladığı faydalar bilinmekle beraber (Sadler, 2004) SBK'ya dayalı öğretimlerin problem çözme ve bu bağlamda yürütülecek yaratıcı yazma becerilerine sunduğu faydalar henüz açığa çıkarılmamıştır. Üstelik SBK'lar toplumsal, ekonomik, din, ahlak ve etik konular açısından disiplinlerarası bir yapıya sahiptir. Bu disiplinlerarası anlayıştan hareketle ilgili çalışma sosyal bilgiler dersi kapsamında ele alınmıştır. Bu kapsamda çalışmada öncelikle problem çözme ve yaratıcı yazma çalışmaları değerlendirilmiştir.

Problem çözme becerisi hedeflenen amaca erişebilmek için bilgiyi, yaratıcılığı ve hayal gücünü kullanarak güçlükleri yenme süreci olarak tanımlanmaktadır (Özsoy, 2007). Ülkemizde problem çözme becerisi üzerine yapılan araştırmalarda farklı eğitim kademelerinde yer alan öğrenci, öğretmen adayları ve öğretmenlerle çalışıldığı görülmektedir (Köseoğlu, 2014; Tunca, 2004). Bu çalışmalarda problem çözme becerisi doğrudan (Gömleksiz ve Bozpolat, 2012; Koç, 2015; Yazgan, 
2007) incelenmekle birlikte problem çözme becerisinin genellikle fen (Acar, 2018; Kardaş, 2013) ve matematik dersi kapsamında (Karslıgil Ergin, 2015; Kösece Loğoğlu, 2016; Özsoy, 2005) ele alındığı görülmektedir. Ancak problem çözme becerisi sosyal bilgiler dersi ile de ilişkilendirilebilmektedir (Tetik, 2013; Uysal, 2010). Bu kapsamda SBK'ya dayalı bir öğretimin ilkokul düzeyindeki çocukların problem çözme becerisi ile yaratıcı yazma becerileri üzerindeki etkisi incelenmeye değer görülmektedir.

Yaratıcı yazma kişinin bir konudaki duygu ve düşüncelerini hayal gücünü kullanarak kâğıda özgürce aktarabilmesidir (Orhon, 2020). Göçer'e (2019) göre ise yaratıcı yazma var olan bilgileri, kavramları, olayları, bellekteki sesleri, görüntüleri ve hayalleri yeniden kurgulayarak birbiriyle ilişkili yeni bir ürün ortaya koyma etkinliğidir. Dolayısıyla gerek problem çözme becerisi gerekse yaratıcı yazma süreci bireylerin bilişsel süreçlerini harekete geçiren unsurlar olarak kabul edilebilmektedir. Bu unsurlar öğrencilerin güncel ve ikilemli bağlamı olan SBK'lar yoluyla incelenebilir. İlgili çalışmalardan hareketle ilkokul 4.sınıf sosyal bilgiler dersi bilim - teknoloji ve toplum ünitesi boyunca yapay zekâ temasında SBK ele alınmış ve SBK'ya dayalı öğretimin, öğrencilerin problem çözme ve yaratıcı yazma becerilerine etkisi incelenmeye çalışılmıştır. Bu amaçla çalışmada oluşturulan araştırma soruları şu şekildedir:

1. Illkokul 4.sınıf öğrencilerine yapay zekâ temasında sunulan SBK içerikli sosyal bilgiler dersinin, öğrencilerin problem çözme ve yaratıcı yazma becerileri üzerindeki etkisi nedir?

2. Öğrencilerin yapay zekâ temalı SBK öğretimlerine yönelik görüşleri nasıldır?

\section{Yöntem}

\section{Araştırma Modeli}

Bu çalışma, nicel ve nitel araştırma yöntemlerinin kombinasyonunu içeren karma yöntem araştırmalarından yakınsayan paralel desen üzerine yapılandırılmıştır. Yakınsayan paralel desende nitel ve nicel veriler beraber toplanmaktadır. Ancak veriler ayrı ayrı analiz edilmekte ve bulguların birbirini doğrulayıp doğrulamadığına bakılmaktadır. Bu desende araştırmacı, zengin veri topluluğuna ulaşmak için hem nitel hem de nicel verileri birlikte toplamaktadır (Creswell, 2004; Cresswell ve Clark, 2014). Çalışmanın nicel kısmında tek grup ön test-son test zayıf deneysel desen kullanılmıştır. Bu desende tek bir grup üzerinde bağımsız değişkenin bağımlı değişken üzerindeki etkisinin tespit edilmesi amaçlanmaktadır (Yıldııım ve Şimşek, 2008). Araştırmanın ikinci aşamasında ise nitel araştırma desenlerinden durum çalışması kullanılmıştır. Illkokul 4.sınıf öğrencileri tek bir durum olarak ele alınmış ve bu kapsamda veri toplama araçları olarak görüşme ve gözlem formları kullanılmıştır.

\section{Çalışma Grubu}

Çalışma 2020-2021 eğitim öğretim yılında Konya ilinde yer alan bir ilkokulun 4.sınıf öğrencileriyle yürütülmüştür. Öğrencilerin $8^{\prime} i \mathrm{kız}, 12$ 'si erkektir. Çalışma grubu belirlenirken uygun örnekleme yöntemi kullanılmıştır. Bu yöntemde zaman, para, konum gibi koşullara bağlı olarak elverişlilik durumuna uygun olacak şekilde örneklem belirlenmektedir (Canbazoğlu Bilici, 2019). Bu çalışmada da araştırmacılar ulaşabildikleri örneklem üzerinde çalışmayı gerçekleştirmişlerdir.

\section{Veri Toplama Araçları}

Çalışmanın nicel kısmında problem çözme envanteri ile yaratıcı yazma ölçeği, nitel kısmında ise gözlem ile görüşme formları kullanılmıştır. Kullanılan veri toplama araçları aşağıda tanıtılıışır. 


\section{Çocuklar için Problem Çözme Envanteri}

Bu çalışmada veri toplama aracı olarak Çocuklar için Problem Çözme Envanteri (Serin, Bulut Serin ve Saygılı, 2010) kullanılmıştır. Illgili envanter ilköğretim öğrencilerinin problem çözme becerisi ile ilgili kendilerini algılama düzeylerini ölçmek amacıyla geliştirilmiştir. Envanterin gelişim sürecine 8 ilköğretim okulunun 4., 5., 6., 7. ve 8. sınıflarda öğrenim görmekte olan toplam 568 öğrenci katılmıştır. Faktör analizi sonucunda envanterin "Problem Çözme Becerisine Güven” (12 madde), "Öz Denetim" (7 madde) ve "Kaçınma" (5 madde) olmak üzere toplam 3 faktör ve 24 maddeden oluşan bir yapıya sahip olduğu görülmüştür. İlgili envanterin tamamının güvenirlik katsayısııın .80 olduğu bildirilmiştir. Bu çalışmada envanter için yapılan güvenirlik analizinde Cronbach Alpha değeri .60 olarak hesaplanmıştır.

\section{Yaratıcı Yazma Ölçeği}

Çalışmada kullanılan diğer veri toplama aracı ise Yaratıcı Yazma Ürünlerini Değerlendirme Ölçeğidir (Kasap, 2019). Ölçeğin araştırma sürecinde 150 ilkokul 4. sınıf öğrencisine yaratıcı yazma çalışması yaptırılmıştır. 24 maddeden oluşan ölçeğin ikinci uygulamasından sonra elde edilen güvenirlik katsayısı .72 olarak hesaplanmıştır. Her öğrencinin ölçekten alabileceği ağırlıklı ham puan en az 24, en çok 120 biçiminde ifade edilmiştir. Bu çalışmada ölçek için yapılan güvenirlik analizinde Cronbach Alpha değeri .95 olarak hesaplanmıştır.

\section{Görüşme Formu}

Çalışma kapsamında öğrencilere 5 adet açık uçlu soru sorulmuştur. Sorular hazırlanmadan önce konuyla ilgili literatür taraması yapılmış ardından nitel çalışmalar yapan bir uzmandan soruların kapsam ve uygunluğu açısından görüş bildirmesi istenmiştir. Hazırlanan görüşme soruları, öğrencilerin uygulama boyunca katıldıkları etkinlikler hakkında ne düşündüklerini ve hissettiklerini belirlemeye yönelik olarak kullanılmıştır.

\section{Gözlem Formu}

Çalışmada öğrencilerin SBK'ya dayalı öğretimleri esnasında sınıf ortamı ve öğrenci katılımlarını gözlemlemek amacıyla yarı yapılandırılmış bir gözlem formu kullanılmıştır. Bu form Topçu'nun (2019) geliştirmiş olduğu Sosyobilimsel Konu Temelli Öğretim için Sınıf Gözlem Protokolünden uyarlanarak kullanıımıştır. Çalışma kapsamında yapay zekânın farklı boyutlarını ele alan 4 adet gözlem formu oluşturulmuştur.

\section{Verilerin Toplanması}

Illkokul 4.sınıf öğrencileriyle yapay zekâ temasında SBK'ların ele alındığı bu çalışma 4 haftalık bir uygulama kapsamında gerçekleştirilmiştir. Uygulama yapılmadan önce ilkokul öğrencilerinin bilişsel seviyeleri dikkate alınarak sınıf içinde yapay zekâ konulu okuma kitaplarının taraması yapılmıştır. İlgili tarama sonucunda öğrencilerin seviyesine uygun görülen Çocuklar İçin Yapay Zekânın Sırları (Koç, 2020) ve Daha İyi Bir Dünya İçin Yapay Zekâ ( Koç ve Kasap, 2019) kitaplarının ilgili bölümleri sınıf içinde okuma çalışmalarında kullanıımıştır. Bu okuma çalışmalarında amaç, öğrencilerin yapay zekâ konusunda temel bir bilgi yapısına sahip olmalarını sağlamaktır. Sınıf içinde okuma çalışmalarına bu şekilde devam edilirken yapay zekâ temelli senaryolarla da sınıf içinde tartışmalar yürütülmüştür. illgili senaryolar, araştırmacılar tarafından literatür taraması yapıldıktan sonra konu ve sınıf düzeyi dikkate alınarak yazılmıştır. Senaryolar yazılırken SBK konusunda daha önce yazılan senaryolar ve bu senaryo yazımlarında dikkat edilmesi gereken hususlara (Atabey vd., 2018) özen gösterilmiştir. Senaryo 
yazımında ilgili literatür incelemesi yapıldıktan sonra yapay zekanın SBK bağlamında farklı açılardan ele alınması için sağlık, eğitim, sosyal (geleceğin meslekleri) ve askeri boyutlarında ilkokul seviyesinde metinler hazırlanmıştır. Bu senaryolar SBK konusunda çalışmaları bulunan 15 doktoralı uzmana gönderilmiştir. Ilgili senaryolar hakkında bu uzmanlardan 5'i dönüş yapmıştır. Uzmanlardan ilgili senaryoları; yapay zekânın SBK senaryosu açısından uygunluğu, ilkokul 4.sınıf düzeyine uygunluğu, dil ve anlatım açısından uygunluğu, senaryoda sunulan olumlu, olumsuz ve tarafsız bilgi ile senaryo sonunda sorulan tartışma sorularının uygunluğu açısından incelemeleri istenmiştir. ilgili uzmanlardan gelen dönütlerden sonra senaryolar üzerinde düzenlemeler yapılmış ve uygulama öncesinde başka bir sınıfta öğrenim gören iki öğrenciye uygulanmıştır. Öğrencilerin senaryoyu ve senaryoda kendisine yöneltilen soruları anlayıp anlamadığı konusundaki tereddütler giderildikten sonra ilgili senaryolar her hafta yapay zekânın bir bağlamını ele alacak şekilde sınıf içinde tartışılmaya başlanmıştır (ilgili senaryolardan biri Ek-1'de sunulmuştur). Tartışmalarda, öğrencilerin yapay zekânın farklı boyutlarında fikir sahibi olabilmelerini sağlaması ve deneyim zenginliği kazandırması açısından Wall-E, Köfte Yağmuru, Köfte Yağmuru 2, Robotlar filmleri de serbest zamanlarda öğrencilere izletilmiştir. 4 haftalık bu uygulamanın öğrencilerin problem çözme becerileri üzerindeki etkisini incelemek amacıyla ilgili envanter ön test-son test olarak öğrencilere uygulanmıştır.

Çalışmada yapay zekâ bağlamında SBK ele alınırken aynı zamanda öğrencilerin yaratıcı yazma ile duygu ve biliş dünyaları hakkında bilgi edinilmeye çalışıımıştır. Bu amaçla 4 haftalık uygulamadan önce öğrencilere istedikleri bir konuda serbest yazma çalışması yaptırılmıştır. Ilggili yazma çalışmaları, araştırmacılar tarafından okunarak birbirinden ayrı kodlanmıştır. ilgili kodlamaların daha sonra benzerlik yüzdesi hesaplanarak standart bir puana dönüştürülmüş ve analiz programına aktarılmıştır. 4 haftalık uygulama boyunca öğrencilere farklı konularda yaratıcı yazma çalışmaları yaptırılmış ve yaratıcı yazma konusunda dikkat edilmesi gereken hususlar konusunda bilgilendirmeler yapılmıştır. Dördüncü haftanın sonunda öğrencilerden yapay zekâyı ele alan bir öykü yazmaları istenmiştir. Öğrencilerin yazdıkları öyküler, ön testte olduğu gibi değerlendirilmiştir. Çalışmada kullanılan tüm ölçme araçları için ilgili izinler alınmış çalışma hakkında öğrenciler ve velileri bilgilendirilmiştir. Bu kapsamda öğrencilerden toplanan veriler, Necmettin Erbakan Üniversitesi Sosyal ve Beşeri Bilimler Bilimsel Araştırmalar Etik Kurulu Başkanlığından 15/01/2021 tarih, 01 sayı ve 2021/34 karar numaralı etik kurul izniyle toplanmıştır. Tüm uygulamalar ve verilerin toplanması çevrimiçi platformlarda gerçekleştirilmiştir.

\section{Verilerin Analizi}

Çalışmada kullanılan nitel ve nicel veri toplama araçları ayrı ayrı analiz edilmiştir. Öncelikle çalışma kapsamında kullanılan problem çözme envanteri ile yaratıcı yazma ölçeğinden elde edilen veriler istatistiksel analizlere tabii tutulmuştur. Yaratıcı yazma ölçeğinden alınan puanlar belirlenirken, öğrencilerin öyküleri 2 ayrı kişi tarafından okunup puanlanmıştır. Ardından puanlayıcılar arası uyuşum yüzdesi hesaplanmıştır. Ön test için uyuşum oranı $\% 85$, son test için uyuşum oranı $\% 88$ olarak hesaplanmıştır. Bu uyuşum yüzdeleri hem ön test hem de son test için oldukça iyi görünmektedir (Tekin, 2019). Grubun ön test ve son test puanları arasındaki farklılığı ölçmek için n<30 olduğundan (Büyüköztürk, 2011) parametrik olmayan yöntemlerden ilişkili ölçümler için Wilcoxon İşaretli Sıralar Testi kullanılmıştır.

Çalışmanın nitel kısmında öğrencilerle çevrimiçi ortamda farklı tarihlerde bireysel görüşmeler gerçekleştirilmiştir. Yapılan görüşmeler kayıt altına alınarak ilgili ifadeler metne dökülmüştür. Öğrencilerin verdikleri yanıtlar içerik analizi ile analiz edilmiş ve temalar oluşturulmuştur. Yarı yapılandırılmış gözlem formunda ise ilgili davranışın gözlenmesi halinde evet, gözlenmemesi halinde hayır, kısmen gözlenmesi halinde ise kısmen durumunu yansıtan kutucuklar işaretlenmiş, gerekli durumlarda açıklamalar yazılmıştır. Gözlem formundan elde edilen veriler, bulgular kısmında özetlenerek sunulmuştur. 


\section{Bulgular}

Çalışmada ilk olarak nicel bulgulara yer verilmiştir. Bu doğrultuda öğrencilerin problem çözme becerilerine ilişkin ön test-son test sonuçları Tablo 1'de sunulmuştur.

Tablo 1.

Problem Çözme Envanterine İlişkin Ön Test-Son Test Sonuçları

\begin{tabular}{ccccccc}
\hline & & N & Sıra Ortalaması Sıra Toplamı & Z & $p$ \\
\hline Özdenetim & Negatif Sıra & 3 & 9.33 & 28.00 & $-2.881^{*}$ & $.004^{* *}$ \\
& Pozitif Sıra & 17 & 10.71 & 182.00 & & \\
& Eşit & 0 & & & & \\
Kaçınma & Negatif Sıra & 16 & 10.00 & 160.00 & $-3.253^{*}$ & $.001^{* *}$ \\
& Pozitif Sıra & 2 & 5.50 & 11.00 & & \\
& Eşit & 1 & & & & \\
Güven & Negatif Sıra & 0 & .00 & .00 & $-3.924^{*}$ & $.000^{* *}$ \\
& Pozitif Sıra & 20 & 10.50 & 210.00 & & \\
& Eşit & 0 & & & & \\
& Negatif Sıra & 2 & 2.50 & 5.00 & $-3.626^{*}$ & $.000^{* *}$ \\
& Pozitif Sıra & 17 & 10.88 & 185.00 & & \\
\hline & Eşit & 0 & & & & \\
\hline
\end{tabular}

* Negatif sıralar temeline dayalı

$* * p<.05$

Tablo 1'e göre çalışma grubunda yer alan öğrencilerin kaçınma alt boyutu dışında, öz denetim ve güven alt boyutlarının uygulama öncesi ve sonrası puanları arasında anlamlı bir fark olduğu görülmektedir $(p<.05)$. Fark puanlarının sıra toplamları dikkate alındığında, gözlenen bu farkın kaçınma boyutunda ön test lehine diğerlerinde ise son test puanı lehine olduğu görülmektedir. Problem çözme envanterinin uygulama öncesi ve sonrası puanları arasında anlamlı bir fark olduğu görülmektedir $(Z=-3.626 ; p<.05)$. Bu durum uygulamanın, öğrencilerin problem çözme becerilerine anlamlı yönde katkı sunduğunu bildirmektedir.

Öğrencilerin uygulama öncesi ve sonrasında yazmış oldukları öykülerin yaratıcı yazma ölçeğine göre değerlendirme sonuçları ise Tablo 2'de sunulmuştur.

Tablo 2.

Yaratıcı Yazma Ölçeğine İlişkin Ön Test-Son Test Sonuçları

\begin{tabular}{ccccccc}
\hline & & N & Sıra Ortalaması & Sıra Toplamı & Z & $P$ \\
\hline Yaratıcı Yazma & Negatif Sıra & 1 & 1.00 & 1.00 & $-3.883^{*}$ & $.000^{* *}$ \\
& Pozitif Sıra & 19 & 11.00 & 209.00 & & \\
& Eşit & 0 & & & & \\
\hline
\end{tabular}

* Negatif sıralar temeline dayalı

$* * p<.05$

Tablo 2'ye göre çalışma grubunda yer alan öğrencilerin yaratıcı yazma uygulama öncesi ve sonrası puanları arasında anlamlı bir fark olduğu görülmektedir $(Z=-3.883 ; p<.05)$. Bu durum uygulamanın, öğrencilerin yaratıcı yazma becerilerine anlamlı yönde katkı sunduğunu bildirmektedir. 
Çalışmanın nitel kısmında öğrencilerle bireysel görüşmeler yapılmış ve verilen cevaplar içerik analizine tabii tutulmuştur. Bu kapsamda öğrencilere uygulamalar esnasında en çok hangi etkinlikten zevk aldıkları sorulmuştur (Şekil 1). Öğrenciler, sınıf içinde yapmış oldukları uygulamalarla ilgili olarak özellikle tartışma uygulamalarından hoşlandıklarını belirtmişlerdir. "Arkadaşlarımla tartışma yapmayı sevdim. Çünkü arkadaşlarımla tartışırken onlar sayesinde olaya farklı bakış açılarından bakabiliyorum", "Ben arkadaşlarımla tartışmalar yapmayı sevdim çünkü kendi görüşlerimi paylaşmayı seviyorum." ifadelerini kullanmışlardır. Sınıf içinde yapılan yaratıcı yazma çalışmaları, film izleme ve kitap okuma uygulamaları da öğrenciler için zevkli ve eğlenceli olarak görülmüştür. Bu konuda öğrenciler "Ben bu süreçte en çok yazı yazma çalışmasını sevdim. Çünkü yazı yazmayı çok seviyorum, aynı zamanda hayal kurmayı da çok seviyorum", "En çok film izlemek hoşuma gitti çünkü hem eğlenceli hem de komikti." açıklamasını yapmışlardır.

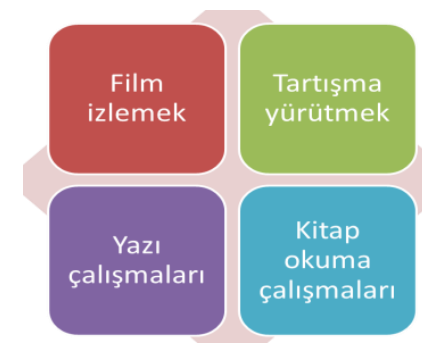

Şekil 1. Öğrencilerin zevk aldıkları uygulamalar

Yapay zekâ konusunda öğrencilerin tamamı, konuyu ilgi çekici bulduklarını ifade etmişler. Yapay zekâ konusunda daha fazla ne öğrenmek istersiniz sorusuna öğrenciler; yapay zekâ uygulamalarına yönelik kodlamalar, ileri teknoloji uygulamaları, geleceğin meslekleri, farklı bilgisayar teknolojileri, robotlar ve yapay zekânın hayvanlarla ilgili çalışma alanlarının neler olduğunu merak ettiklerini ve bu konularda daha fazla bilgiye sahip olmak istediklerini belirtmişlerdir.

Öğrenciler, yapay zekâ temasında yürütülen SBK içerikli derslerle ilgili gerçekleştirilen uygulamalardan hoşlandıklarını ve bu uygulamaların dersi daha fazla sevmelerini sağladığını belirtmişlerdir. Bu konuda öğrenciler; "Dersi bu şekilde işlemek sevmemi sağladı, kendimi rahat hissettim", "Evet etkiledi, hayal gücüm çok gelişti. Zaten seviyordum böylelikle daha çok sevdim", "Çok etkiledi daha çok seviyorum. Arkadaşlarımla konuşarak yapınca daha eğlenceli oldu." biçiminde ifadeler kullanmışlardır. Öğrencilere son olarak, yürütülen bu uygulamalarda ne hissettikleri sorulmuştur. Öğrenciler bu uygulamalarda kendilerini mutlu, şaşkın ve iyi hissettiklerini belirtmişlerdir. SBK bağlamlı tartışmalarla ilgili olarak bir kız öğrenci; "Bu tartışmalarda kendimi mutlu ve iyi hissettim. Bu tartışmalar sırasında bazen arkadaşlarıma hak verdim bazen de kendi fikrimi savundum." ifadesini kullanmıştır. Başka bir kız öğrenci de "Derslerde yürüttügü̈müz tartışmalarda kendimi heyecanlı ve mutlu hissettim. Tartışma sırasında farklı görüşler beni olumlu etkiledi. Onlara hak verdim çünkü herkesin görüşü farklı olabilir ve biz buna saygı duymalıyız" demiş, erkek öğrencilerden biri ise "Derslerde yürüttüğümüz tartışmalar sırasında kendimi mutlu ve heyecanlı hissettim. Tartışma sırasında arkadaşlarımın görüşlerine bazen hak verirken bazen vermiyorum." şeklinde açıklama yapmıştır.

Yapay zekâ konusunda hazırlanan senaryolarda öğrenci tartışmaları yarı yapılandırılmış gözlem formu ile değerlendirilmiştir. İlgili formda kategorilerin bulunma, bulunmama ya da kısmen bulunma durumlarına göre maddeler frekanslara dönüştürülmüştür. Böylece öğrencilerdeki değişim durumu daha iyi açıklanmaya çalışılımışı (Tablo 3). 
Tablo 3.

Gözlem Formundan Elde Edilen Bulgular

\begin{tabular}{|c|c|c|c|}
\hline GÖZLEM KATEGORILERI & Evet & Hayır & Kısmen \\
\hline SBK Tartışmalarında Öğrencinin Rolü & \multicolumn{3}{|c|}{ Görülme Sıklıkları $(f)$} \\
\hline 1)Öğrenciler tartışmalara katılır. & 2 & & 2 \\
\hline 2) Öğrenciler SBK'nın eğitim/ sağlık/ askeri/ sosyal boyutunu tartışır. & 2 & & 2 \\
\hline 3) Öğrenciler SBK'nın riskli ve faydalı yönlerini değerlendirir. & 3 & & 1 \\
\hline $\begin{array}{l}\text { 4) Öğrenciler SBK ile ilgili okudukları kitap ve izledikleri filmden } \\
\text { hareketle veri toplayıp analiz eder. }\end{array}$ & 1 & 1 & 2 \\
\hline 5) Öğrenciler SBK'nın ilgili boyutunda kendi fikirlerini beyan eder. & 2 & 1 & 1 \\
\hline \multicolumn{4}{|l|}{ SBK Tartışmalarında Sınıf Ortamı } \\
\hline 1) Öğrenciler arası işbirlikli ve etkileşimli bir öğrenme ortamı vardır. & 2 & & 2 \\
\hline $\begin{array}{l}\text { 2) Öğretmen ve öğrencilerin birbirine saygı gösterdiği bir öğrenme } \\
\text { ortamı vardır. }\end{array}$ & 2 & & 2 \\
\hline
\end{tabular}

Tablo 3'te yapay zekânın eğitim, sağlık, sosyal ve askeri boyutlarında hazırlanan senaryolarının sınıf ortamında tartışılması esnasındaki gözlem sonuçları özetlenmiştir. SBK bağlamlı ilk senaryo olan eğitim boyutunda yapılan gözlemlerde; öğrencilerin bir kısmı uygulama sırasında aktif olarak söz alırken bazı öğrenciler fikir belirtmemeyi tercih etmiş, farklı fikirlere olumlu bir yaklaşım sergilenmemiş, karşılıklı konuşmalar gerçekleşmiş ama daha çok kendi fikrini açıklamak için tartışmalar gerçekleştirilmiştir. Ayrıca öğrencilerden bazıları karşı görüşe sert tepkiler vermiş kendi söylediklerinin daha doğru olduğu konusunda direnç göstermişlerdir. Yapay zekânın son bağlamı olarak ele alınan sosyal bağlamda geleceğin mesleklerine yer verilmiş ve son uygulama gerçekleştirilmiştir. Bu uygulamada ilk uygulamadan farklı olarak öğrenciler, arkadaşlarının görüşlerini dinlemiş birbirlerinin konuşmalarını desteklemiş ayrıca örnekler vererek birbirlerine destek olmuşlardır. Öğrenciler arasında birbirlerinin görüşlerini merakla bekleyen bir tavır oluşmuş, tek bir düşünceyi savunmak yerine farklı açılardan bakarak değerlendirme yapmaya başlamışlardır. Bu hâliyle gözlemden elde edilen bulguların, görüşmeden elde edilen bulgularla tutarlı olduğu görülmektedir.

\section{Tartışma, Sonuç ve Öneriler}

Illkokul 4.sınıf öğrencilerine yapay zekâ temasında sunulan SBK öğretiminin, öğrencilerin problem çözme ve yaratıcı düşünme becerilerine olan etkisinin incelendiği bu çalışmada hem nitel hem de nicel veri toplama araçları kullanılmıştır. Illgili araçlarla toplanan verilerin analizinde, öğrencilere güncel bir konudan hareketle sunulan SBK öğretiminin hem problem çözme hem de yaratıcı düşünme becerileri üzerinde etkili olduğu tespit edilmiştir. Peel ve arkadaşları (2019) SBK'ya dayalı öğretiminin öğrencilerin özellikle bilişsel becerileri üzerinde etkili olduğunu ifade etmişlerdir. Benzer şekilde Alkış Küçükaydın (2020) SBK'ya yönelik tutumların sorgulama becerileri üzerindeki etkisine değinmiştir. SBK'nın bilişsel beceriler üzerindeki etkisi, bilginin daha çok güncel eğitsel bağlamlardan ele alınmasıyla ilişkilendirilmektedir (Leung, 2020). Bu çalışmada da güncel ve tartışmalı bir konu olan yapay zekâ, SBK niteliğinde ele alınmıştır. Ilgili literatür, SBK'ya dayalı öğretimlerin öğrencilerin argümantasyon becerileri (Topçu ve Atabey, 2017), organ nakli konusunda farkındalık (Tetik ve Cebesoy, 2018), öğretmen adaylarında araştırma davranışlarında ilerleme (Gürbüzoğlu vd., 2016) ile öz-yeterlik ve epistemolojik inançlarında farklılaşmaya (Baltacı, 2013) katkı sağladığını göstermiştir. Bu çalışmada ise daha önce ele alınmayan bir tema olarak yapay zekâ, SBK senaryoları ile ilkokul öğrencilerine sunulmuş ve bilişsel becerilere katkı sağladığı görülmüştür. Bunun sebebi öğrencilerin sadece senaryolarla SBK'yı ele almaları değil hem okuma hem de öğrendikleri bilgileri yaratıcı yazma çalışmaları ile uygulamaya geçirmiş olmalarından kaynaklanıyor olabilir. Bu şekilde 
öğrencilere sadece SBK'nın ne olduğu değil SBK kapsamındaki bir konunun tartışılmaya açılmasıyla kendi gerçekliği içinde öğrenilmesine fırsat tanınmıştır. Öğrenciler bu doğrultuda yaratıcı öykü denemeleri gerçekleştirmişlerdir. Bu durum da öğrencilerin birden fazla alanda bilişsel beceri kazanmalarına katkı sunmuş olabilir.

Yine oldukça güncel ve ilkokul öğrencilerinin ilgisini çeken yapay zekâ konusunun seçilmesi öğrencilerin tartışmalara daha gönüllü katıımasını sağlamış olabilir. Nitekim öğrencilerle yapılan görüşmeler de bu sonucu destekler niteliktedir. Taşçı ve Çelebi (2020) yapay zekânın günümüz müfredatlarında artık kaçınılmaz bir yere sahip olduğunu, öğrenci, öğretmen ve öğretim elemanlarının bu bağlamdan uzak durmalarııı çağın gereklerini yerine getirmemek anlamına geldiğini ifade etmişlerdir. Yeni ve güncel bir konu olarak yapay zekânın seçilmesi belki de öğrencilerin yaratıcılıklarına bu açıdan katkı sunmuştur. Özcan ve Kaptan (2020) SBK'lara yönelik konuların doküman analizini yaptıkları çalışmalarında SBK'ya yönelik güncel tasarımların yer alacağı program ihtiyacına vurgu yapmışlardır. İlkokul sosyal bilgiler ders programında (MEB, 2018) doğrudan SBK'yı vurgulayan bir kazanım yer almamasına rağmen toplum-teknoloji-çevre kazanımları yer almakta ve bu kazanımlar öğrenci ihtiyaçlarına göre şekillendirilebilmektedir. Dolayısıyla bu çalışmada olduğu ilgili kazanım güncel ihtiyaçlarla sınıf ortamına taşınabilmektedir. Sadler (2004) öğrencilerin ilgi ve ihtiyaçları doğrultusunda öğretmenlerin stratejik değişiklikler yapabileceklerini vurgulamıştır. Buna dayanarak ilkokulda farklı ve güncel konulardan hareketle SBK öğretimleri yapılabilir. Bu öğretimler için program değişikliğine intiyaç duyulmayabilir.

Çalışmada ilkokul öğrencilerinin yaratıcı yazma ve problem çözme becerilerinde anlamlı düzeyde ilerlemeler olduğu görülmüştür. Lee ve arkadaşları (2020) sınıf ortamında uygun SBK'ların sunulması halinde öğrencilerin üstbilişsel becerilerinde gelişme olacağını işaret etmişlerdir. Bu durum ilgili SBK öğretimlerinin kapsamının genişletilmesi halinde farklı sonuçlara ulaşılabileceğini de göstermektedir. Bu nedenle ilkokul düzeyinde tematik bir yaklaşımla SBK öğretiminin yapılacak olması öğrencilerde üstbilişsel becerilere de katkı sunabilir. Bunun anlaşılabilmesi için sınıf içi uygulamaların artırılması ve bu doğrultuda yeni araştırmaların yürütülmesi gerekmektedir. Bu uygulamalar esnasında yine güncel konuların seçimi oldukça önemlidir. Evren Yapıcıoğlu'nun (2020) da önerdiği üzere ilkokul düzeyinde hazırlanacak SBK etkinlikleri ile bu uygulamaları yapmak mümkündür. Böylece öğrencilerin bizzat yaşadıkları bir durumdan hareketle problem çözme ve yaratıcı yazma çalışmaları dışında eleştirel düşünme ya da informal akıl yürütme gibi farklı bilişsel düşünce yapıları açığa çıkarılabilir. 


\section{Kaynakça}

Acar, D. (2018). FeTeMM eğitiminin ilkokul 4. sınıf öğrencilerinin akademik başarı, eleştirel düşünme ve problem çözme becerisi üzerine etkisi. Yayınlanmamış doktora tezi, Gazi Üniversitesi, Ankara.

Alkış Küçükaydın, M. (2019). Sekizinci sınıf öğrencilerinin sosyobilimsel bir konuya ilişkin görüşleri ve argüman yapıları. Ilköğretim Online, 18(1), 174-189.

Alkış Küçükaydın, M. (2020). Sınıf öğretmeni adaylarının sosyobilimsel konulara yönelik tutumları ile sorgulama becerileri arasındaki ilişkinin incelenmesi. Milli Eğitim Dergisi, 49(225), 181-200.

Arslan, H. S. ve Çiğdemoğlu C. (2020). Sosyobilimsel konuların öğretiminde öğretmen rolleri ve mentorluk. M. Genç (Ed.) İçinde Kuramdan uygulamaya sosyobilimsel konular (s.371-396). Ankara: Nobel Yayıncılık

Atabey, N., Topçu, M. S. ve Çiftçi, A. (2018). Sosyobilimsel konu senaryolarının incelenmesi: Bir içerik analizi çalışması. Uluslararası Toplum Araştırma Dergisi, 9 (16), 1968-1991.

Atalay, M. ve Çelik, E. (2017). Büyük veri analizinde yapay zekâ ve makine öğrenmesi uygulamaları. Mehmet Akif Ersoy Üniversitesi Sosyal Bilimler Enstitüsü Dergisi, 19 (22), 155-172.

Ateş, H. ve Saraçoğlu, M. (2013). Fen bilgisi öğretmen adaylarının gözünden nükleer enerji. Ahi Evran Üniversitesi Kırşehir Eğitim Fakültesi Dergisi, 14(3), 175-193.

Baltacı, S. (2013). Fen ve teknoloji öğretmen adaylarının sosyobilimsel bir konudaki (GDO’lu besinler) öğretim öz yeterlilikleri ve bu yeterliliklerin epistemolojik inançlar ile ilişkileri (Yayınlanmamış yüksek lisans tezi). Abant İzzet Baysal Üniversitesi, Bolu.

BBC News (2018). Yapay zekâ dini şiddeti engelleyebilir mi? https://www.bbc.com/turkce/haberler-dunya46044214 adresinden erişilmiştir.

Büyüköztürk, Ş. (2011). Sosyal bilimler için veri analizi el kitabı istatistik, araştırma deseni SPSS uygulamaları ve yorum. Ankara: Pegem Akademi.

Canbazoğlu Bilici, S. (2019). Örnekleme yöntemleri. H.Özmen ve O. Karamustafaoğlu (Ed.) İçinde Eğitimde araştırma yöntemleri (s.56-78). Ankara: Pegem Akademi.

Cresswell, J. W. and Clark, V. L.P. (2014). Foundations of mixed method researches. London: Sage Publications.

Creswell, J. W. (2014). A concise introduction to mixed methods research. London: Sage Publications.

Çelik, A. (1998). Bilgi toplumu üzerine bazı notlar. Hacettepe Üniversitesi Edebiyat Fakültesi Dergisi, 15(1), 5359.

Demir, B. ve Düzleyen, E. (2012, Haziran). Illköğretim 8. sınıf öğrencilerinin GDO bilgi düzeylerinin incelenmesi. X. Ulusal Fen Bilimleri ve Matematik Eğitimi Kongresi, Niğde.

Demircioğlu, T. ve Uçar, S. (2014). Akkuyu nükleer santrali konusunda üretilen yazılı argümanların incelenmesi. ilköğretim Online, 13(4), 1373-1386.

Eş, H., Işık Mercan, S. ve Ayas, C . (2016). Türkiye için yeni bir sosyo-bilimsel tartışma: Nükleer ile yaşam. Turkish Journal of Education, 5 (2) , 47-59.

Evren Yapıcıoğlu, A. (2020). Fen eğitiminde sosyobilimsel konu olarak COVID 19 pandemisi ve örnek uygulama önerileri. Milli Eğitim Dergisi, 49(1), 1121-1141.

Göçer, A. (2019). Yazma eğitimi. Ankara: Pegem Akademi.

Gömleksiz, M. N. ve Bozpolat, E. (2012). İlköğretim 4. ve 5. Sınıf öğrencilerinin problem çözme becerilerine ilişkin görüşlerinin değerlendirilmesi. Abant izzet Baysal Üniversitesi Eğitim Fakültesi Dergisi, 12(2), 2340.

Gürbüzoğlu Yalmancı, S. ve Gözüm, A.I.C. (2016). Fen bilgisi öğretmen adaylarının (GDO) sosyo-bilimsel konusuna yönelik araştırma davranışlarının incelenmesi. Ahi Evran Üniversitesi Kırşehir Eğitim Fakültesi Dergisi, 17( 1), 499-515.

Harman, G. ve Çökelez, A. (2017). Fen bilgisi öğretmen adaylarının sosyo-bilimsel bir konu olan organ bağışına yönelik metaforik algıları. Uşak Üniversitesi Sosyal Bilimler Dergisi, 10(1), 55-70.

İseri, B. (2012). Fen ve teknoloji öğretmen adaylarının nükleer enerjinin riskleri ve faydalı hakkındaki düşüncelerine farklı bilgi kaynaklarının etkileri (Yayınlanmamış yüksek lisans tezi). Ahi Evran Üniversitesi, Kırşehir.

Kardaş, N. (2013). Fen eğitiminde argümantasyon odaklı öğretimin öğrencilerin karar verme ve problem çözme becerilerine etkisi (Yayınlanmamış yüksek lisans tezi). Eskişehir Osmangazi Üniversitesi, Eskişehir.

Karslıgil Ergin, G. (2015). Öğrencilerin problem çözme ve kurma süreçlerindeki matematiksel düşünmelerinin incelenmesi (Yayınlanmamış yüksek lisans tezi). Gaziantep Üniversitesi, Gaziantep.

Kasap, D. (2019). Yaratıcı okuma-yaratıcı yazma çalışmalarının yaratıcı okuma, okuduğunu anlama, yazma ve yaratıcı yazma erişisine etkisi (Yayınlanmamış doktora tezi). Pamukkale Üniversitesi, Denizli. 
Kılınç, A., Boyes, E. ve Stanisstreet M. (2013). Exploring students' ideas about risks and benefits of nuclear power using risk perception theories. Journal of Science Education and Technology, 22, 252-266.

Kim, G., Ko, Y. and Lee, H. (2020). The effects of community-based socioscientific issues program (SSI-COMM) on promoting students' sense of place and character as citizens. International Journal of Science and Mathematics Education, 18(3), 399-418.

Koç, C. (2015). illköğretim öğrencilerinin problem çözme becerilerine yönelik algıları ve öğrenme sürecinde yardım istemeleri. Kastamonu Üniversitesi Kastamonu Eğitim Dergisi, 23(2), 659-678.

Koç, O. (2020). Çocuklar için yapay zekânın sırları daha iyi bir dünya için yapay zekâ. İstanbul: Doğan Egmont Yayıncılık.

Koç, O. ve Kasap, M. (2019). Daha iyi bir dünya için yapay zekâ. İstanbul: Doğan Egmont Yayıncılık.

Kösece Loğoğlu, P. (2016). Polya'nın problem çözme yöntemine dayalı etkinliklerle matematik öğretiminin ilkokul 4.sını öğrencilerinin matematik problemi çözme başarılarına etkisi (Yayınlanmamış yüksek lisans tezi).Mersin Üniversitesi, Mersin.

Köseoğlu, E. (2014). Illkokul 4. sınıflarda drama etkinlikleriyle işlenen derslerin öğrencilerin problem çözme ve karar verme becerileri üzerindeki etkilerinin incelenmesi (Yayınlanmamış yüksek lisans tezi). Atatürk Üniversitesi, Erzurum.

Kutluca, A. Y. (2012). Fen ve teknoloji öğretmen adaylarının klonlamaya ilişkin bilimsel ve sosyobilimsel argümantasyon kalitelerinin alan bilgisi yönünden incelenmesi (Yayınlanmamış yüksek lisans tezi). Abant İzzet Baysal Üniversitesi, Bolu.

Lee, H., Chang, H., Choi, K., Kim, S.-W. ve Zeidler, D.L. (2012). Developing character and values for global citizens: Analysis of pre-service science teachers' moral reasoning on socioscientific issues. International Journal of Science Education, 34(6), 925-953.

Lee, H., Lee, H. ve Zeidler, D. L. (2020). Examining tensions in the socioscientific issues classroom: Students' border crossings into a new culture of science. Journal of Research in Science Teaching, 57(5), 672-694.

Leung, J. S. C. (2020). A practice-based approach to learning nature of science through socioscientific issues. Research in Science Education, 1-27.

Leung, J. S. C. and Cheng, M. M. W. (2020). Conceptual change in socioscientific issues: Learning about obesity. International Journal of Science Education, 1-25.

Milli Eğitim Bakanlığı (2018). Sosyal bilgiler dersi öğretim programı (illkokul ve ortaokul 1, 2, 3, 4, 5, 6, 7 ve 8. sınıflar). Ankara: Devlet Basımevi.

NTV (2020). Elon Musk'tan “yapay zekâ” açıklaması https://www.ntv.com.tr/galeri/teknoloji/elon-musktanyapay-zeka-aciklamasi,VBzKFREVfEyDI5tqO2EO4g/fjNDYaZYQOelRNLFeNRfyg adresinden erişilmiştir.

Orhon, G. (2020). Yine yazı yazıyoruz. Ankara: Pegem Akademi.

Özcan, C. ve Kaptan, F. (2020). 2008-2017 yılları arasında sosyobilimsel konulara ilişkin yapılan çalışmaların incelenmesi. Muallim Rıfat Eğitim Fakültesi Dergisi, 2(1), 16-36.

Özdemir, N. (2014). Sosyobilimsel esaslar çerçevesinde sosyo-bilimsel konuları tartışmak tutumları nasıl etkiler? Nükleer santraller. Turkish Studies, 9(2), 1197-1214.

Özdemir, N. ve Çobanoğlu, E. O. (2008). Türkiye'de nükleer santrallerin kurulması ve nükleer enerji kullanımı konusundaki öğretmen adaylarının tutumları. Hacettepe Üniversitesi Eğitim Fakültesi Dergisi, 34, 218232.

Özsoy, G. (2005). Problem çözme becerisi ile matematik başarısı arasındaki ilişki. Gazi Eğitim Fakültesi Dergisi, 25(3), 179-190.

Özsoy, G. (2007). Illköğretim beşinci sınıfta üstbiliş stratejileri öğretiminin problem çözme başarısına etkisi (Yayınlanmamış doktora tezi). Gazi Üniversitesi, Ankara.

Özsoy, T. ve Kılınç, A. (2017). Beşinci sınıf öğrencilerinin sosyobilimsel konulara dayalı fen öğretimi (FESKÖK pedagojisi) ile ilgili görüşleri. Uludağ Üniversitesi Eğitim Fakültesi Dergisi, 30(2), 909-925.

Öztürk, K. ve Şahin, M. E. (2018). Yapay sinir ağları ve yapay zekâya genel bir bakış. Takvim-i Vekayi, 6(2), 25-36.

Öztürk, N. (2011). Fen bilgisi öğretmen adaylarının sosyobilimsel konulara ilişkin kritik düşünme yeteneklerinin, epistemolojik inançlarının ve üstbilişsel farkındalıklarının incelenmesi: Nükleer enerji santralleri örneği (Yayınlanmamış yüksek lisans tezi)., Orta Doğu Teknik Üniversitesi, Ankara.

Öztürk, N. ve Irmak, M. (2020). Sosyobilimsel konuların doğası ve fen eğitimindeki yeri. M. Genç (Ed.) İçinde Kuramdan uygulamaya sosyobilimsel konular (s.15-44). Ankara: Nobel Yayıncılık.

Öztürk, N., ve Türköz, G. (2019). İzle- düşün- tartış: Sosyo-bilimsel konuların öğretimine ilişkin bir etkinlik örneği. Araştırma Temelli Etkinlik Dergisi, 9(1), 14-24. 
Öztürk, S. ve Leblebicioğlu, G. (2014). Sosyo-bilimsel bir konu olan hidroelektrik santraller (HES) hakkında karar verilirken kullanılan irdeleme şekillerinin incelenmesi. Necatibey Eğitim Fakültesi Elektronik Fen ve Matematik Eğitimi Dergisi, 9(2), 1-33.

Peel, A., Zangori, L., Friedrichsen,P., Hayes, E. ve Sadler, T. (2019) Students' model-based explanations about natural selection and antibiotic resistance through socio-scientific issues-based learning. International Journal of Science Education, 41(4), 510-532.

Peel, A., Sadler, T., Kinslow, A., Zangori, L. ve Friedrichsen, P. (2017). Climate change as an issue for socioscientific issues teaching and learning. D.P. Hepardson, A. Roychoudhury, A. S. Hirsch (Eds.) In Teaching and learning about climate change: A framework for educators (p.153-165). New York: Routledge.

Ritchie, S.M., Tomas, L. and Tones, M. (2011). Writing stories to enhance scientific literacy. International Journal of Science Education, 33(5), 685-707.

Sadler, T. D. (2004). Informal reasoning regarding socioscientific issues: A critical review of research. Journal of Research in Science Teaching, 41(5), 513-536.

Serin, O., Bulut Serin, N. ve Saygılı, G. (2010). Illköğretim düzeyindeki çocuklar için problem çözme envanterinin (ÇPÇE) geliştirilmesi. Ilköğretim Online, 9(2), 446-458.

Soysal, Y. (2012). Sosyobilimsel argümantasyon kalitesine alan bilgisi düzeyinin etkisi: Genetiği değiştirilmiş organizmalar (Yayınlanmamış yüksek lisans tezi). Abant İzzet Baysal Üniversitesi, Bolu

Taşçı, G. ve Çelebi M. (2020). Eğitimde yeni bir paradigma: "Yükseköğretimde yapay zekâ". Uluslararası Toplum Araştırmaları Dergisi, 16 (29), 2346-2370.

Tekbıyık, A. (2015). The use of jigsaw collaborative learning method in teaching socio-scientific issues: The case of nuclear energy. Journal of Baltic Science Education, 14(2), 237-253.

Tekin, H. (2019). Eğitimde ölçme ve değerlendirme. Ankara: Yargı Akademi.

Tetik, A. T. (2013). Sosyal bilgiler dersinde kullanılan probleme dayalı öğrenme yönteminin öğrencilerin karar verme becerisine etkisi (Yayınlanmamış yüksek lisans tezi).Mehmet Akif Ersoy Üniversitesi, Burdur.

Tetik, S., ve Cebesoy, Ü. B. (2018). Ortaokul öğrencilerinin organ bağışına ve nakline yönelik görüşlerinin incelenmesi. Kuramsal Eğitimbilim Dergisi, 11(3), 486-506.

Topçu, M. S. ve Atabey, N. (2017). Sosyobilimsel konu içerikli alan gezilerinin ilköğretim öğrencilerinin argümantasyon nitelikleri üzerine etkisi. Bartın Üniversitesi Eğitim Fakültesi Dergisi, 6(1), 68-84.

Topçu, M.S. (2019). Sosyobilimsel konu öğretimi. Ankara: Pegem Akademi.

Tunca, M. (2004). Meslek lisesi öğretmenlerinin duygusal zekâları ile problem çözme becerileri arasındaki ilişkinin araştırılması (Yayınlanmamış yüksek lisans tezi). Marmara Üniversitesi, İstanbul.

Ural Keleş, P. (2018). Kök hücre konulu seminerin fen bilgisi öğretmen adaylarının bilişsel yapılarına etkisi. Uluslararası Eğitim Bilim ve Teknoloji Dergisi, 4(1) , 41-57.

Uysal, G. (2010). ilköğretim sosyal bilgiler dersinde işbirlikli öğrenmenin erişiye, problem çözme becerilerine, öğrenme stillerine etkisi ve öğrenci görüşleri (Yayınlanmamış doktora tezi). Dokuz Eylül Üniversitesi, İzmir.

Yacoubian, H. A. ve Khishfe, R. (2018). Argumentation, critical thinking, nature of science and socioscientific issues: A dialogue between two researchers. International Journal of Science Education, 40(7), 796807.

Yavuz Topaloğlu, M. ve Balkan Kıyıcı, F. (2018). Okul dışı öğrenme ortamlarında yürütülen etkinliklerin öğrencilerin sosyobilimsel konulara ilişkin görüşlerine etkisi: Organ bağışı ve GDO. E-Uluslararası Eğitim Araştırmaları Dergisi, 9(1), 36-50.

Yazgan, Y. (2007). Dördüncü ve beşinci sınıf öğrencilerinin rutin olmayan problem çözme stratejileriyle ilgili gözlemler. Ilköğretim Online, 6(2), 249-263.

Yıldırım, A. ve Şimşek, H. (2008). Sosyal bilimlerde nitel araştırma yöntemleri (6. Baskı). Ankara: Seçkin Yayıncılık.

Zengin, F., Keçeci, G. ve Kırılmazkaya, G. (2012). İlköğretim öğrencilerinin nükleer enerji sosyo-bilimsel konusunu online argümantasyon yöntemi ile öğrenmesi. Education Sciences, 7(2) , 647-654. 


\section{EK-1. Yapay Zekânın Eğitim Boyutunu Ele Alan SBK Senaryosu}

Yapay zekâ ve artırılmış gerçeklik sayesinde kimi uzmanlık alanları için uzun süren eğitimlere devam etmeye gerek kalmıyor. Diyelim ki teknik bir personel olarak çalışıyorsunuz ve uçak motoru tamir edeceksiniz. Bu tamiri yapabilmek için ciddi bir teknik bilgiye ve bu bilgiye sahip olabilmek için de uzun süreli bir eğitime dolayısıyla masraflarınızı karşılayacak bir gelire ihtiyacınız var. Ancak siz bu imkânlara sahip olmadan da tamir işini yapabilirsiniz. Yapay zekâ donanımlı artırılmış gerçeklik gözlükleri sayesinde motoru oluşturan parçalar tanımlanabilmekte ve gerekli yönlendirmeler ile tamir işi çok hızlı bir şekilde yapılabilmektedir. Üstelik bu gözlükler sayesinde yanlış takılan parçalar algılanıp, uyarı sistemi devreye girmektedir. Sistem sayesinde hem zamandan tasarruf edilmekte hem de eğitim giderlerinin karşılanması için gereken masraf da asgari seviyeye inmektedir. Ayrıca yapay zekâ donanımlı bu gözlüklere, üretilen tüm veri setlerini yüklemek mümkündür. Fakat bu durum herhangi bir konuda hiç eğitim almamış ve kötü niyetli insanların amaçlarına ulaşmalarını da hızlandırabilir. Tüm bilgilerin yüklü olduğu bir gözlük ile insansız bir hava aracı üretmek bununla belli kişi ya da kişileri hedef alarak yok etmek de mümkün.

Kimi bilim insanları gelecekte matematik, felsefe ya da fen bilimleri gibi disiplinlerin öğretilmesine gerek olmayacağını çünkü zaten her türden bilginin böyle gözlüklere yüklenebileceğini ve hayatımızın kolaylaşacağını iddia etmektedirler. Peki, sizce gerçekten öyle mi, yapay zekânın sunduğu imkânlarla hayatımızın kolaylaşacağına inanıyor musunuz? 